\title{
Treatment of the Poisoned Child
}

\author{
DAVID H. S. REID \\ From the Children's Hospital, Birkenhead
}

\begin{abstract}
Reid, D. H. S. (1970). Archives of Disease in Childhood, 45, 428. Treatment of the poisoned child. Syrup of ipecac has measurable advantages over gastric lavage in evacuating the stomach of children with accidental poisoning, in terms of safety, effectiveness, and rapidity of action.

The average period for action with ipecac is likely to be about 17 minutes, or 82 minutes, depending on whether the child is treated at home or in hospital.

In contrast, the mean delay to completion of gastric lavage is estimated at 126 minutes, and this procedure has little place in the treatment of the child with poisoning.
\end{abstract}

The immediate treatment of acute poisoning is the elimination of the ingested poison from the stomach. At present, there is lack of agreement as to whether this should be achieved by gastric lavage, by emesis with ipecacuanha (ipecac), or by administration of adsorptive charcoal. This study seeks to compare ipecac-induced emesis with gastric lavage in the treatment of acute poisoning in children. Both forms of therapy have a venerable history extending back into the mists of medical mythology. Ipecac, derived from the dried root or rhizome of Cephaelis acuminata or ipecacuanha, had long been in use in Central and South America as a remedy for dysentery before it was brought to Europe by Piso (1648, 1658), who recognized its emetic qualities. In recent years it has been shown that the two main alkaloids of ipecac, emetine and cephaline, act by a central effect on the vomiting centre in the lateral reticular formation of the medulla, and also peripherally on the gastro-intestinal mucosa (Borison and Wang, 1953). The procedure of inserting a foreign body into the pharynx and oesophagus for the purpose of emptying the stomach was described by Suetonius in his life of the Caesars: 'It was seldom that Claudius left a dining-hall except gorged and sodden; he would then go to bed and sleep supine with his mouth wide open-thus allowing a feather to be put down his throat, which would bring up the superfluous food and drink as vomit.' The introduction of gastric lavage into medical

$\star$ In the Personal Practice series of articles an author is invited to give his own views on some current practical problem. practice was established on a more scientific basis a $\stackrel{\Phi}{\oplus}$ hundred years ago by Adolf Kussmaul (1869). Though gastric lavage has been generally con-. sidered during the last century to be the accepted form of initial therapy of acute poisoning, it is only recently that it has been claimed that syrup of ipecac has significant advantages over gastric lavage in evacuating the stomach (Shirkey, 1966). The $\stackrel{\square}{\varnothing}$ purpose of this paper is to assess these claims and, $\overrightarrow{\vec{F}}$ in particular, to study the relative rapidity of action $\frac{3}{3}$ of ipecac-induced emesis with that of gastric lavage.

\section{Patients and Methods}

During 1967 and 1968, 426 children with accidental poisoning attended this hospital (Table I). None of these patients was unconscious and emesis was attempted with ipecac syrup in 224 cases. Ipecac was not 3 given to children who were known with certainty to have consumed an inconsequential amount of poison, or who $\frac{}{\partial}$

TABLE I

Source of Poisons in 426 Cases of Poisoning in Children

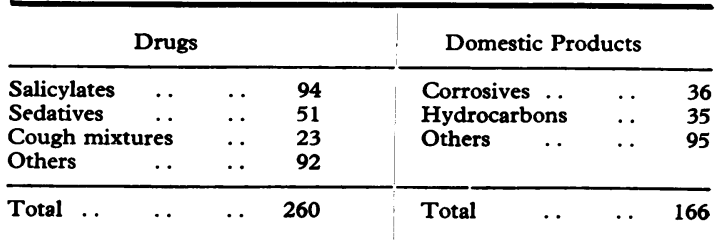


had taken corrosives or petroleum products. The usual dose of ipecac syrup, U.S.P.^, was $15 \mathrm{ml}$. followed by $200 \mathrm{ml}$. water or clear fluid. A further $15 \mathrm{ml}$. ipecac syrup was repeated once if no vomiting occurred within 20-25 minutes. The dose was varied slightly with the size of the child and the nature of the poisoning. $10 \mathrm{ml}$. was given to especially small children, or if they had taken drugs which might in themselves have caused vomiting; $20 \mathrm{ml}$. was prescribed if the child was particularly large or had consumed an anti-emetic drug. Thoman and Verhulst (1966) showed that the efficacy of ipecac syrup was unimpaired by anti-emetic drugs, but it was considered prudent to give a larger dose than normal in these circumstances.

Further investigations were performed during 1969 to assess the period of delay between ingestion of a poison and completion of gastric lavage. Apart from the latent period in travelling from home to hospital, additional time may be taken awaiting the initiation of gastric lavage in a busy emergency room. The period of delay between arrival in the accident department of this hospital and attention by a medical officer was therefore recorded in 100 consecutive patients presenting with a variety of acute complaints.

To estimate the duration of gastric lavage this procedure was performed on 25 conscious children with acute poisoning by a modification of the method of Dreisbach (1966). The modification consisted of introducing fluid by a funnel and repeating the lavage 20 times or until the siphoning fluid was clear.

\section{Results}

Twenty-two of the records were incomplete and thus of the 224 cases 202 records were adequate for analysis. Emesis was induced after ipecac syrup in $98 \%$ of cases, and the average time for action was 17 minutes in these patients.

The frequency of emesis after ipecac syrup is shown in Table II. Frequent vomiting may have

TABLE II

Number of Vomitings After Syrup of Ipecac

\begin{tabular}{c|c|c}
\hline No. of Vomitings & No. of Patients & $\%$ \\
\hline 0 & 4 & 2 \\
1 & 95 & 47 \\
2 & 73 & 36 \\
3 & 28 & 14 \\
4 & 2 & 1 \\
\hline & 202 & 100 \\
\hline
\end{tabular}

been due to the ipecac syrup or to the ingested poison, but no untoward effects occurred as a result of treatment with ipecac and there were no fatalities.

Of the 426 children seen during the two-year

*The formula may be written as follows: Liquid extract of ipecac (BP) $7 \mathrm{ml}$; glycerine $10 \mathrm{ml}$; and syrup to $100 \mathrm{ml}$.

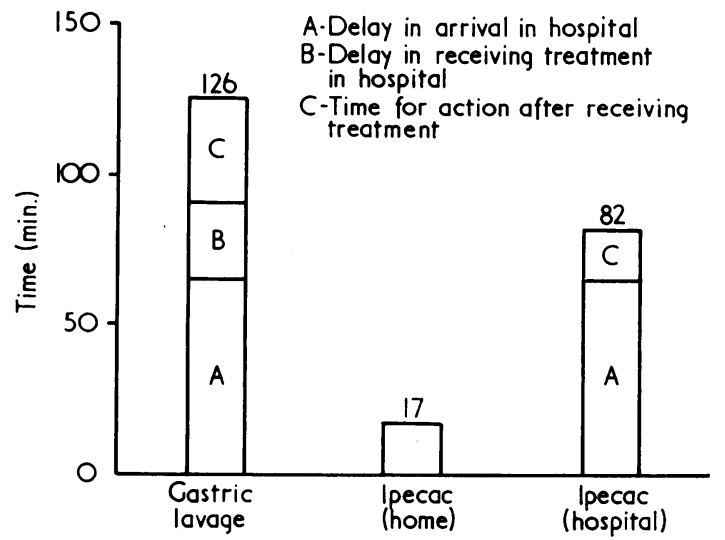

Fig.-Total time elapsing between ingestion of poison and treatment. The figure describes the events shown in Table III.

period (1967-8), data were available in 373 patients documenting the time interval between poisoning and attendance in this hospital. The mean delay between ingestion of the poison and arrival in the emergency room was 65 minutes. The mean period of delay between arrival in the accident department and attention by a casualty officer was found to be 26 minutes. The mean duration of the procedure of gastric lavage was 35 minutes. Comparison of the total time required for completion of gastric lavage and for emesis with ipecac syrup is shown in Table III and the Figure.

\section{TABLE III}

Time- Required for Completion of Gastric Lavage and for Emesis with Ipecac Syrup

Gastric Lavage Time

Time A: 65 minutes-from ingestion of poison to arrival in accident centre

Time B: 26 minutes-delay in receiving medical attention in accident centre

Time C: 35 minutes-time required for lavage

Total time $=126$ minutes

Time Required for Emesis with Ipecac Syrup

1: If patient at home-17 minutes-time required for action with ipecac

2: If patient attends hospital.

Time $A-65$ minutes-from ingestion of poison to arrival in accident centre

Time $\mathrm{C}-17$ minutes-time required for action with ipecac

Total time $=17$ or 82 minutes 


\section{Discussion}

During the past decade, following the classical studies of Arnold, Hodges, and Barta (1959), and other workers in America, it has been suggested that syrup of ipecac has significant advantages over gastric lavage in evacuating the stomach in terms of safety, effectiveness, and rapidity of action (Shirkey, 1966). These claims can now be considered briefly in order.

The ancient adage of primum non nocere is of prime importance in accidental poisoning in children, a condition associated with a mortality which may be as low as 1 per 35,000 (Corby et al., 1968). There have been no reported instances of poisoning from $30 \mathrm{ml}$. or less of ipecac syrup (Shirkey, 1966). It is important to be aware of the difference between the syrup and other preparations of ipecac, whose dangers prohibit their prescription. In particular, the fluid extract is 14 times more concentrated and has resulted in fatalities (Smith and Smith, 1961). Provided that the syrup is used and the recommended dose is not exceeded no complications attributable to the systemic toxicity of ipecac syrup have been recorded among 7,461 reports (Shirkey, 1966). The most important complication of gastric lavage is impairment of pulmonary function. The first critical examination of lavage performed by Harstad, Møller, and Simesen (1942) showed that particles of charcoal added to the lavage fluid could later be recovered in the pulmonary tissues of patients who died. Allan (1961) regarded gastric lavage as 'potentially dangerous' in all patients. Geall (1966) reported that, 'routine lavage is associated with a surprising morbidity, due mainly to inhalation of stomach contents and to laryngeal spasm with subsequent anoxia'. Aspiration of fluid into the lungs with development of pulmonary complications and pneumonia occurred in 3\% of patients as a result of gastric lavage (Matthew et al., 1966). Sefi (1968) stated that, 'from simple observations on conscious children treated by emesis with syrup of ipecac, and conscious children treated by gastric lavage, it seems obvious that the clean and easy vomit induced by ipecac does not soil the lower airways. Invariably, passing a stomach tube in a conscious child under emergency room conditions induces gross gagging, vomiting through and around the tube, gross contamination of the upper airways, and obvious contamination of the lower airways, with glottic irritation. This is shown by brief cyanosis and convulsive deep, crowing inspirations in response, which seems to be an ideal condition for aspiration.' The risks of gastric lavage are not limited to respiratory embarrassment. Burston
(1969) performed stomach lavage in 27 adult patients with severe salicylate self-poisoning. Three of these patients $(11 \%)$ developed gastric haemorrhage during lavage as a result of which $\overrightarrow{0}$ the procedure had to be abandoned. Further 듬 complications that have been reported include $\frac{\bar{\sigma}}{\bar{D}}$ damage to the stomach (British Medical Journal, $\widehat{\Phi}_{0}$ 1964), perforation of the oesophagus (Matthew et al., 1966), and cardiac arrest (Lee and Ames, $s$ 1965). The psychological sequelae of stomach $\vec{\circ}$ lavage have not been adequately studied but they $\overrightarrow{\vec{\omega}}$ may be as important as the physical consequences. $\stackrel{\omega}{\sigma}$ Certainly, the cries of a child undergoing this ordeal have an adverse effect on the relatives, and the whole tenor of the casualty department suffers of as well. It is clear that the complications of gastric in lavage may in themselves require emergency treat- $\vec{\square}$ ment. For example, if the stomach contents are $\stackrel{+}{N}$ inhaled, immediate bronchoscopic suction, intra- $\infty$ venous steroids, and administration of oxygen may $\stackrel{5}{2}$ be necessary (Wingate, 1969), each of which $\vec{c}$ involves further risks. It is also possible that though accidental poisoning in children is becoming ${ }^{\infty}$ common, fatalities are rare, and the risks of gastric $\vec{\varphi}$ lavage may exceed those of the initial $\stackrel{0}{0}$ poisoning.

Assessment of the relative efficacy of ipecacinduced emesis and gastric lavage in removing poison from the stomach of children can be considered in two ways. First, by comparison of the $\mathbb{D}$ incidence of successful induction of evacuation of $\underset{\vec{F}}{\overrightarrow{2}}$ the stomach in a series of patients. Ipecac syrup $\frac{0}{3}$ was followed by vomiting in $98 \%$ of patients in this study. This experience accords well with reports of a $98 \%$ (Alpert, 1969), and 100\% (Dabbous, Bergman, and Robertson, 1965) incidence of vomiting following the use of syrup of ipecac. : Data on the success rate of gastric lavage are surprisingly sparse. Gastric lavage had to be $\delta$ abandoned in 5 of 71 patients $(7 \%)$ in the series 3 of Burston (1969) and in 3 of 76 patients (4\%) in 응 the experience of Allan (1961), giving a success rate of $93 \%$ and $96 \%$, respectively, in these two series of patients. Secondly, the efficiency of syrup of ipecac and gastric lavage can be estimated o by the percentage recovery of ingested poison in $N$ individual patients in whom evacuation of the N stomach has been achieved by these means. The $\sigma$ studies of Harstad et al. (1942) showed that gastric lavage was generally inefficient and often valueless in acute poisoning. Not more than about $3 \%$ of any drug taken was removed by gastric lavage, except for quinine of which $12 \%$ was recovered. Furthermore, radiological examination indicated $\overrightarrow{\mathbb{D}}$ that lavage tended to promote the passage of poison 
into the intestine (Journal of the American Medical Association, 1947).

Allan (1961) reported that gastric lavage removed only small quantities of ingested barbiturate, and was of no value in most cases. Its limitations in removing solid matter such as tablets are obvious. Clemmesen and Nilsson (1961) recorded their findings with several thousand patients with barbiturate poisoning treated between 1948 and 1959. The mortality rate fell from 12 to $1.5 \%$ with improved methods of treatment including the omission of gastric lavage. Matthew et al. (1966) recovered more than $200 \mathrm{mg}$. barbiturate in only $17 \%$ of patients with barbiturate poisoning treated with gastric lavage.

Investigations of the relative merits of gastric lavage and ipecac syrup in paediatric poisoning are limited by obvious ethical considerations. Dogs were selected by Arnold et al. (1959) as the experimental animals because it was considered that their gastric function and emptying time were similar to those of children. These workers showed that lavage carried out one hour after ingestion of sodium salicylate removed $13 \%$ of the retained dose. In contrast, when ipecac was given within the same time interval $39 \%$ of the ingested poison was recovered. Abdallah and Tye (1967) compared the effects in young dogs of syrup of ipecac, apomorphine hydrochloride, and lobeline sulphate with gastric lavage by measuring the percentage recovery of a test meal of barium sulphate. At 60 minutes time lapse after administration of the test meal all drugs were significantly superior to lavage in emptying the stomach.

Careful studies of salicylate poisoning in children by Boxer, Anderson, and Rowe (1969) have shown that after emesis induced by ipecac only a small residue of salicylate remained which could be removed by lavage, but, conversely, after lavage significantly greater quantities of salicylate could be removed by ipecac-induced emesis. These investigations give considerable support to the view that ipecac-induced emesis is the more efficient method of initial therapy of paediatric poisoning.

Delay in the induction of emesis with ipecac has been criticized by Matthew (1969), with the inference that action with gastric lavage is immediate and instantaneous. Though the time for action with ipecac is well known, corresponding data for gastric lavage are less well documented. Robertson (1962) commented that 'although gastric lavage is frequently endorsed as the treatment of choice, no data are available documenting the rapidity with which it is usually instituted in a busy emergency room'. Done (1965) suggests that emesis is, 'probably a satisfactory substitute for the more laborious and time-consuming gastric lavage, and an additional advantage is that it can usually be accomplished much earlier, often in the home'. Gosselin and Smith (1966) state that the average latency of syrup of ipecac, 'seems rather long, but even more time is probably required to complete an adequate gastric lavage'. Further evidence of delay in the initiation of lavage is provided by a recent press report in which a coroner criticized a casualty department after a 22 -month baby with salicylate poisoning was kept waiting for 'about $\mathbf{4 0}$ minutes before treatment with gastric lavage', and later died in hospital in the South of England (The Times, 1968). Alpert (1969) has also referred to the time-lag in setting up gastric lavage. The average times for vomiting after ipecac have varied from 15 minutes (Corby et al., 1968), 17 minutes (Dabbous et al., 1965), 17 minutes in this report, 18.7 minutes (Robertson, 1962), and 19 minutes (Gosselin and Smith, 1966). Ipecac syrup may be administered in the home by the parent upon medical advice, which could be given by telephone, so that the time between ingestion and action with ipecac syrup may be as low as $\mathbf{1 7}$ minutes if medical advice is obtained immediately at home. If the patient is brought to hospital there is always a nurse in an accident centre available to give ipecac syrup to the poisoned child immediately on his arrival. The average time between ingestion of a poison and action of ipecac syrup is in these circumstances likely to be about 82 minutes if the patient attends hospital-made up of 65 minutes' delay in arrival in hospital, and 17 minutes' time for action after ipecac (Table III). In contrast, gastric lavage, a procedure associated with a high morbidity, must be carried out in hospital by a doctor who may not always be so immediately available. Wingate (1969) has affirmed that, it may be tempting to delegate the manœuvre to the nursing staff, but it is unwise; it is the responsibility of the doctor to be able and ready to perform gastric lavage when necessary'. The average period of delay between arrival in the accident department of this hospital and attention by a medical officer was found to be 26 minutes, giving an estimated average total time-lag from ingestion of the poison to completion of gastric lavage of about 126 minutes (Table III).

Paediatric poisoning is a time of profound stress to the child's relatives whose suffering is mollified with the initiation of treatment. The advantages of immediate therapy with ipecac in the home will be apparent to parents as well as to paediatricians. 
When ipecac is given in the home there should be no delay in attending hospital. Motion is an important part in inducing emesis (Alpert, 1969), and action is likely before arrival in the accident centre.

Evacuation of the stomach, whether by ipecac syrup or by gastric lavage is contraindicated in poisoning with corrosives, petroleum products, or strychnine, whose specialized treatment is outside the scope of this study. In unconscious patients ipecac syrup is contraindicated. There is considerable support for the opinion that gastric lavage also is contraindicated in comatose patients (Harstad et al., 1942; Journal of the American Medical Association, 1947; Nilsson, 1951; Clemmesen and Nilsson, 1961; Allan, 1961 ; Arena, 1963; Myschetzky, 1964; Lee and Ames, 1965; Jacobziner, 1966). The place for gastric lavage in paediatric poisoning is extremely uncertain. The abandonment of the procedure in this unit during the past three years has not been associated with any fatalities among a series of over 600 patients with acute poisoning. It is suggested that this essentially barbaric procedure could be relegated to a suitable chamber of horrors. Adsorbtive charcoal (Arena, 1963) may be administered in the small minority of patients who do not respond to ipecac. The emetic drugs apomorphine hydrochloride and copper sulphate have been advocated as alternatives to ipecac syrup, but their toxicity may preclude them from serious clinical consideration (Arnold et al., 1959; Beckman, 1961; Deichmann and Gerarde, 1964; Gosselin and Smith, 1966; Shirkey, 1966). The ineffectiveness of mechanically induced vomiting has been well documented (Dabbous et al., 1965).

The rapid increase in acute poisoning in recent years has led to various proposals-such as a method of identification of tablets with an imprint system (Whitney, 1960), the use of a child-resistant container (Breault, 1967), and a means of coding, labelling, and safety packaging of poisonous household products (Hart, 1968)-aimed at reducing the incidence of the present epidemic of paediatric poisoning. The metabolic response to poisoning in children differs considerably from that in adult patients (Levi, 1968), and it is apparent that there is little similarity between the two entities (Table IV). Nevertheless, many poisoning centres are controlled by physicians unfamiliar with the characteristics of poisoning in the small child.

Optimal treatment of paediatric poisoning demands the establishment of special paediatric poisoning centres directed by consultants concerned with the special problems of poisoning in children.
TABLE IV

Differences in Poisoning in Children and Adults

\begin{tabular}{l|l|l}
\hline & \multicolumn{1}{|c}{ Children } & \multicolumn{1}{|c}{ Adults } \\
\hline 1: Type of poisoning & Accidental & Suicidal \\
2: Commonest drug & Salicylates & Barbiturates \\
3: Coma & $<1 \%$ 20\% (Burke, 1969) \\
4: Mortality & $1: 35,000$ (Corby & $1-8 \%$ (Teitelbaum, \\
& et al., 1968) & 1967 ) \\
\hline
\end{tabular}

\section{REFERENCES}

Abdallah, A. H., and Tye, A. (1967). A comparison of the efficacy of emetic drugs and stomach lavage. American fournal of Diseases of Children, 113, 571.

Allan, B. C. (1961). The role of gastric lavage in the treatment of patients suffering from barbiturate overdosage. Medical fournal of Australia, 2, 513.

Alpert, J. J. (1969). Removing ingested poison. Lancet, 1, 728.

Arena, J. M. (1963). Poisoning: Chemistry, Symptoms, Treatments. C. C. Thomas, Springfield, Illinois.

Arnold, F. J., Jr., Hodges, J. B., Jr., and Barta, R. A., Jr. (1959). Evaluation of the efficacy of lavage and induced emesis in treatment of salicylate poisoning. Pediatrics, 23, 286.

Beckman, H. (1961). Pharmacology: The Nature, Action and Use of Drugs, 2nd ed. p. 487 . Saunders, Philadelphia.

Borison, H. L., and Wang, S. C. (1953). Physiology and pharmacology of vomiting. Pharmacological Reviews, 5, 193.

Boxer, L., Anderson, F. P., and Rowe, D. S. (1969). Comparison of ipecac-induced emesis with gastric lavage in the treatment of acute salicylate ingestion. Fournal of Pediatrics, 74, 800 .

Breault, H. J. (1967). Household products-obsolete containersinevitable poisonings. Pediatrics, 40, 159.

British Medical fournal (1964). Today's Drugs. Treatment of acute poisoning-1. $2,927$.

Burke, M. (1969). Hospital treatment of acute poisoning. Lancet, $1,306$.

Burston, G. R. (1969). Severe self-poisoning in Sunderland. British Medical fournal, 1, 679.

Clemmesen, C., and Nilsson, E. (1961). Therapeutic trends in the treatment of barbiturate poisoning. The Scandinavian method. Clinical Pharmacology and Therapeutics, 2, 220.

Corby, D. G., Decker, W. J., Moran, M. J., and Payne, C. E. (1968). Clinical comparison of pharmacologic emetics in children. Pediatrics, 42, 361 .

Dabbous, I. A., Bergman, A. B., and Robertson, W. O. (1965). The ineffectiveness of mechanically induced vomiting. Fournal of Pediatrics, 66, 952.

Deichmann, W. B., and Gerarde, H. W. (1964). Symptomatology and Therapy of Toxicological Emergencies. Academic Press, New York.

Done, A. K. (1965). Salicylate poisoning. Fournal of the American Medical Association, $192,770$.

Dreisbach, R. H. (1966). Handbook of Poisoning, 5th ed. Lange, Los Altos, California.

Geall, M. (1966). The management of barbiturate intoxication. Hospital Medicine, 1, 51.

Gosselin, R. E., and Smith, R. P. (1966). Trends in the therapy of acute poisonings. Clinical Pharmacology and Therapeutics, 7, 279.

Harstad, E., Møller, K. O., and Simesen, M. H. (1942). UUber den Wert der Magenspülung bei der Behandlung von akuten Vergiftungen. Acta Medica Scandinavica, 112, 478.

Hart, C. (1968). Personal view. British Medical fournal, 4, 52. Jacobziner, H. (1966). Poisonings in childhood. Advances in Pediatrics, 14, 55.

Fournal of the American Medical Association (1947). Editorial. Value of gastric lavage in treatment of acute poisoning. 133, 545.

Kussmaul, A. (1869). Ueber die Behandlung der Magenerweiterung durch eine neue Methode, mittelst der Magenpumpe. Deutsches Archiv für klinische Medizin, 6, 455.

Lee, H. A., and Ames, A. C. (1965). Haemodialysis in severe barbiturate poisoning. British Medical fournal, 1, 1217. 
Levi, A. J. (1968). Poisoning. In Recent Advances in Medicine. Ed. by D. N. Baron, N. Compston, and A. M. Dawson. 15th ed. p. 65. Churchill, London.

Matthew, H. (1969). Removing ingested poison. Lancet, 1, 418. -, Mackintosh, T. F., Tompsett, S. L., and Cameron, J. C. (1966). Gastric aspiration and lavage in acute poisoning. British Medical fournal, 1, 1333.

Myschetzky, A. (1964). The Poison Centre in Copenhagen. Proceedings of the Royal Society of Medicine, 57, 811.

Nilsson, E. (1951). On treatment of barbiturate poisoning. Acta Medica Scandinavica, suppl., 253.

Piso, G. (1648). G. Pisonis . . . De Medicina Brasiliensi Libri Quatuor ... et G. Marcgravii . . . Historiae Rerum Naturalium Brasiliae Libri Octo. (Historia naturalis Brasiliae.) F. Hackius, Leyden.

- (1658). De Indiae Utriusque Re Naturali et Medica Libri Quatuordecim. L. \& D. Elzevir, Amsterdam.

Robertson, W. O. (1962). Syrup of ipecac-a slow or fast emetic ? American fournal of Diseases of Children, 103, 136.
Sefi, R. (1968). Poisoning with hydrocarbon distillates. New England Fournal of Medicine, 278, 49.

Shirkey, H. C. (1966). Ipecac syrup. Its use as an emetic in poison control. Fournal of Pediatrics, 69, 139.

Smith, R. P., and Smith, D. M. (1961). Acute ipecac poisoning. New England fournal of Medicine, 265, 523.

Suetonius. The Twelve Caesars, translated by Robert Graves (1967). Penguin Books, Harmondsworth, Middlesex.

Teitelbaum, D. T. (1967). Fatalities from poisoning too high in United States. New England fournal of Medicine, 277, 1039.

The Times (1968). Coroner criticizes hospital. 28 September, p. 3.

Thoman, M. E., and Verhulst, H. L. (1966). Ipecac syrup in antiemetic ingestion. Fournal of the American Medical Association, 186, 433.

Whitney, J. D. W. (1960). The identification of tablets. British Medical fournal, 1, 50.

Wingate, D. L. (1969). Gastric lavage in acute poisoning. British fournal of Hospital Medicine, 2, 775.

The following articles will appear in future issues of this journal:

Output of Luteinizing Hormone in the Urine of Normal Children and those with Advanced Sexual Development. By J. M. H. Buckler and B. E. Clayton.

Cryptorchidism, Chest Deformities and Other Congenital Anomalies in Three Brothers. By L. H. B. M. van Benthem, O. Driessen, G. T. Haneveld, and H. P. Rietema.

Muscle Biopsy Measurement of Body Water and Intracellular Electrolytes in Children. By J. A. Graham and W. G. Scobie.

Ventilator Therapy in the Newborn: Some Mechanical Considerations. By C. G. Picton-Warlow.

A Disorder of Tryptophan Metabolism in Chronic Granulomatous Disease. By A. F. Heeley, M. E. Heeley, J. Hardy, and J. F. Soothill.

Differential Protein Clearance in Indian Children with the Nephrotic Syndrome. By R. K. Chandra, S. S. Manchanda, R. N. Srivastava and J. F. Soothill.

Personal Practice: The XY Female Child. By C. J. Dewhurst.

Plasma Calcium and Magnesium in Newborn Babies. By D. R. Harvey, L. V. Cooper, and J. F. Stevens. Lymph Node Biopsy in Infants and Children. By B. Bhandari and A. Jain.

Congenital Tuberculosis. By E. Koutsouleris and E. Kaslaris.

Recurrent Haemophilus Septicaemia and Immunoglobulin Deficiency. By R. J. Farrand.

Osteogenesis Imperfecta Tarda Treated with Sodium Fluoride. By J. A. Kuzemko.

Annotation: Folate Deficiency in Premature Infants. By A. V. Hoffbrand.

A Controlled Trial of Assisted Ventilation using an Oro-nasal Mask. By M. A. Llewellyn, K. S. Tilak, and P. R. Swyer.

Growth of Children with Thalassaemia: the Effect of Different Transfusion Regimes. By C. Kattamis, N. Touliatos, S. Haidas and N. Matsaniotis.

Albumin Excretion as a Measure of Glomerular Dysfunction in Children. By T. M. Barratt, P. N. McLaine, and J. F. Soothill.

Giardiasis in Childhood: Absorption Tests and Biochemical, Histochemical, Light, and Electron Microscopy of Jejunal Mucosa. By D. Barbieri, T. De Brito, S. Hoshino, O. B. Nascimento, J. V. Martins Campos, G. Quarentei, and E. Marcondes.

Annotation: Aerosol Therapy in Cystic Fibrosis. By M. B. Mearns.

Plasma Cortisol Levels in the Neonatal Period. By J. F. Stevens.

Transient Gluten Intolerance. By J. A. Walker-Smith.

Hypoprothrombinaemic Bleeding in Infants Associated with Diarrhoea and Antibiotics. By $\mathbf{N}$. Matsaniotis, J. Messaritakis and C. Vlachou.

Immune Deficiency State in a Girl with Eczema and Low Serum IgM. By D. I. K. Evans and A. Holzel. The Physiological Response to Exercise in Children with Lung or Heart Disease. By S. Godfrey.

Secondary Haemorrhagic Disease of the Newborn. By J. M. Chessells and J. S. Wigglesworth.

Serum Levels of Fibrin/Fibrinogen Degradation Products in the Haemolytic Uraemic Syndrome. By W. S. Uttley.

Comparison of Serum Growth Hormone Levels after Bovril and Insulin Stimulation. By D. B. Grant, D. Jackson, S. Raiti, and B. E. Clayton.

Use of Random Specimens of Urine to Compare the Dietary Intakes of African and British Children.

By E. M. Widdowson and R. A. McCance. 